\title{
Respons Kalus Embriogenik Tanaman Tebu (Saccharum Officinarum) Var. Kidang Kencana Terhadap Berbagi Modifikasi Media Kultur Dalam Proses Induksi Akar
}

\author{
Embryogenic Callus Responses of Sugarcane (Saccharum Officinarum) var. kidang kencana \\ Towards Various Modification of Culture Media in the Process of Root Induction
}

\author{
Sri Habsari Puji Astuti*, Wiwik Indrawati, Dedi Supriyatdi, Jakty Kusuma \\ Program Studi Produksi dan Manajemen Industri Perkebunan, Politeknik Negeri Lampung \\ *e-mail: s.habsarip@gmail.com
}

\begin{abstract}
ABSTRAK
Tebu (Saccharum officinarum) merupakan salah satu bahan penghasil gula utama di Indonesia dan memiliki peran penting dalam perekonomian Indonesia dan menjadi sumber devisa negara. Kemenperin mencatat, produksi gula nasional hanya mencapai angka 2,17 juta ton. Sementara, kebutuhan gula nasional mencapai 66 juta ton. Ini menandakan Indonesia baru mampu memenuhi 3,29\% dari total kebutuhan nasional, sehingga lebih dari 96\% defisit kebutuhan gula nasional yang belum mampu dan harus dipenuhi Indonesia.. Tujuan dari penelitian ini adalah mendapatkan komposisi media kultur yang tepat dan optimal untuk pertumbuhan akar dari kalus embriogenik tanaman tebu. Penelitian ini bertempat di Laboraturium Kultur Jaringan Politeknik Negeri Lampung. Proses induksi akar ini dilakukan melalui modifikasi media MS dengan campuran IAA, Kinetin, CM, 2,4-D, dan sukrosa yang dilakukan dengan Rancangan Acak Kelompok. Variabel yang diamati adalah respons kalus, waktu tumbuh akar, panjang akar dan jumlah akar. Hasil penelitian dan pengujian menunjukkan bahwa komposisi media berpengaruh terhadap perkembangan akar. Media dengan kombinasi IAA menghasilkan respons berupa akar, namun media dengan kombinasi 2,4-D memberikan respons berupa pelebaran kalus. Hasil pengamatan menunjukkan perlakuan terbaik untuk pengakaran adalah kombinasi media IAA $1 \mathrm{mg} . \mathrm{l}^{-1}$ baik berupa ratarata panjang 1,56 cm dan jumlah akar 2,08.
\end{abstract}

Kata kunci: Kultur jaringan, induksi akar, tanaman tebu

\section{ABSTRACT}

Sugarcane (Saccharum officinarum) is one of the main sugar-producing ingredients in Indonesia and has an important role in the Indonesian economy and is a source of foreign exchange. The Ministry of Industry noted that the national sugar production only reached 2.17 million tons. Meanwhile, the national sugar requirement reaches 66 million tons. This indicates that Indonesia has only been able to meet $3.29 \%$ of the total national demand, so that more than $96 \%$ of the deficit in national sugar demand is not able and must be fulfilled by Indonesia. The aim of this research is to obtain the appropriate and optimal composition of culture media for root growth from embryogenic callus of sugarcane. This research took place at the Lampung State Polytechnic Network Culture Laboratory. The root induction process was carried out by modifying MS media with a mixture of IAA, Kinetin, CM, 2,4-D, and sucrose which was carried out in a randomized block design. The variables observed were callus response, root growth time, root length and number of roots. The results of the research and testing indicated that the composition of the media had an effect on root development. Media with combination of IAA produced a response in the form of roots, but media with combination of 2,4-D gave a response in the form of callus 
widening. The results showed that the best treatment for rooting was a combination of IAA 1 mg.l-1 medium both in the form of an average length of $1.56 \mathrm{~cm}$ and a number of roots of 2.08 .

Keywords: Tissue culture, root induction, sugarcane

\section{PENDAHULUAN}

Tebu (Saccharum officinarum) merupakan salah satu bahan penghasil gula utama di Indonesia dan memiliki peran penting dalam perekonomian Indonesia dan menjadi sumber devisa negara. Kemenperin (2018) mencatat, produksi gula nasional hanya mencapai angka 2,17 juta ton. Sementara, kebutuhan gula nasional mencapai 66 juta ton. Ini menandakan Indonesia baru mampu memenuhi 3,29\% dari total kebutuhan nasional, sehingga lebih dari 96\% defisit kebutuhan gula nasional yang belum mampu dan harus dipenuhi Indonesia.

Sejalan dengan pemenuhan kebutuhan gula nasional, perlu dilakukannya perluasan areal dan penyediaan bibit bermutu 1.5 sampai 2 milliar bibit pertahun untuk mendukung peningkatan produksi gula yang selama 3 dasawarsa ini terus mengalami kemerosotan. Umumnya perbanyakan bibit tebu masih menggunakan metode konvensional melalui stek (vegetatif). Metode konvensional ini memiliki beberapa kekurangan antara lain harus memiliki lahan yang luas, tanaman induk serta tenaga kerja yang cukup banyak, masih tergantung kepada musim tanam, serta tingkat kontaminasi patogen yang tinggi sehingga sulit dihidari (Minarsih, 2013).

Kekurangan bibit dalam jumlah banyak ini dapat diatasi dengan menggunakan metode kultur jaringan. Kultur Jaringan sudah diaplikasikan untuk mendapatkan produksi bibit secara massal, efisien secara biaya, cepat, dan tentunya bebas patogen di berbagai tanaman pangan, hortikultura, dan industri (Bahera dan Sahoo, 2009).

Lestari dan Husni (1997) melaporkan penggunaan IAA $1 \mathrm{mg} / \mathrm{l}$ terbukti menghasilkan akar terbanyak dibandingkan dengan perlakuan lainnya pada tanaman inggu. Pada tanaman Mukikachu (Colocasia esculenta) IAA terbaik untuk pertumbuhan akar justru pada konsentrasi 0,5 mg/l. (Bhuiyan, et al. 2011). Wijayanti, Isda, dan Lestari (2015) melaporkan perlakuan sukrosa 3\% pada induksi tanaman jeruk siam (Citrus nabilis Lour.) memberikan pengaruh signifikan pada panjang akar dan jumlah akar dibandingkan dengan taraf sukrosa yang lain. Pada pengakaran tebu sukrosa yang tepat dalam merangsang jumlah akar terbaik adalah dosis 5\%. (Samudera et al., 2019).

Oleh karena itu, metode kultur jaringan merupakan solusi terbaik untuk melakukan perbanyakan bibit tebu massal yang unggul, bebas patogen dalam waktu yang relatif singkat.

\section{METODE PENELITIAN}

Penelitian ini dilaksanakan pada bulan Desember 2019 hingga Januari 2020 bertempat di Laboraturium kultur jaringan Politeknik Negeri Lampung. Penelitian ini menggunakan Rancangan Acak Kelompok (RAK) dengan 4 perlakuan komposisi media tanam dengan zpt yang berbeda (Tabel 1) dan diulang sebanyak 6 kali sehingga diperoleh 24 satuan percobaan. 
Tabel 1. Komposisi Media Kultur

\begin{tabular}{|c|c|c|}
\hline No & Bahan & Media \\
\hline 1 & $\mathrm{MS}+\mathrm{IAA}\left(0,5 \mathrm{mg} \cdot \mathrm{l}^{-1}\right)+\operatorname{kin}\left(0,2 \mathrm{mg} \cdot \mathrm{l}^{-1}\right)+\mathrm{CM}\left(70 \mathrm{ml} \cdot \mathrm{l}^{-1}\right)+$ sucrosa $3 \%$ & M1 \\
\hline 2. & $\mathrm{MS}+\mathrm{IAA}\left(1 \mathrm{mg} . l^{-1}\right)+\operatorname{kin}\left(0,2 \mathrm{mg} \cdot l^{-1}\right)+\mathrm{CM}\left(70 \mathrm{ml} . l^{-1}\right)+$ sucrosa $5 \%$ & M2 \\
\hline 4 & $\mathrm{MS}+2,4-\mathrm{D}\left(1 \mathrm{mg} . l^{-1}\right)+\operatorname{kin}\left(0,2 \mathrm{mg} \cdot l^{-1}\right)+\mathrm{CM}\left(70 \mathrm{ml} \cdot l^{-1}\right)+$ sucrosa $3 \%$ & M3 \\
\hline 3. & $\mathrm{MS}+2,4-\mathrm{D}\left(1,5 \mathrm{mg} \cdot l^{-1}\right)+\mathrm{kin}\left(0,2 \mathrm{mg} \cdot l^{-1}\right)+\mathrm{CM}\left(70 \mathrm{ml} \cdot \mathrm{l}^{-1}\right)+$ sucrosa $5 \%$ & M4 \\
\hline
\end{tabular}

\begin{tabular}{lll}
\hline Keterangan: & MS & $=$ Murashige dan skoog \\
& IAA & $=$ Indil Acetic Acid (Auksin) \\
Kin & $=$ Kinetin (Sitokinin) \\
CM & $=$ Coconut Milk (Air Kelapa) \\
Sucrosa & $=$ Gula \\
$2,4 \mathrm{D}$ & $=2,4$ Diclorophenoxy Acetic Acid (Auksin)
\end{tabular}

Tahapan awal penelitian ini adalah pembuatan media kultur, Alat-alat yang akan digunakan seperti botol dicuci bersih mengunakan sabun, kemudian dikeringkan dan dtutup dengan plastik bagian atasnya serta ikat dengan karet dan disterilkan menggunakan autoklaf pada suhu $121^{\circ} \mathrm{C}$ selama 60 Menit.

Media dasar yang digunakan untuk perlakuan adalah media MS. Larutan MS dibuat terlebih dahulu sebelum membuat media. Untuk menghomoggenkan 2,4 D dan IAA di dalam larutan menggunakan magnetic stirrer. Setelah larutan stok siap, dikombinasikan sesuai dengan tabel formulasi MS dan tabel perlakuan. Media memerlukan penyesuaian $\mathrm{pH}$ yaitu berkisar antara 5,7-5,9. Untuk menyesuaikan $\mathrm{pH}$ digunakan larutan $\mathrm{KOH} 1 \mathrm{~N}$ bila $\mathrm{pH}$ berada dibawah kisaran yang dikehendaki dan larutan $\mathrm{HCl} 1 \mathrm{~N}$ bila $\mathrm{pH}$ diatas kisaran tersebut. Media dipadatkan dengan cara menambahkan agar $7 \mathrm{~g} . l^{-1}$ sedikit demi sedikit sambil diaduk sampai homogen dan mendidih. Media yang telah dimasak dimasukan kedalam botol kultur. Satu Liter media kultur dibagi ke dalam 25 botol kultur, sehingga volume media dalam satu botol adalah $40 \mathrm{ml}$, lalu tutup menggunakan plastik bening tahan panas dan diikat dengan karet hingga rapat. Botol kultur yang telah diisi media disterilkan menggunakan autoklaf selama 20 menit pada suhu $121^{\circ} \mathrm{C}$.

Penanaman kalus embriogenik pada media kultur dilakukan di dalam Laminar Air Flow Cabinet dengan kondisi aseptik dengan ukuran kalus $0,5 \mathrm{~cm}$. Eksplan yang telah ditanam diinkubasi 21-35 hari sampai muncul akar didalam ruangan terang bersuhu $20-22^{\circ} \mathrm{C}$.

Variabel yang diamati adalah respons kalus embriogenik (3, 4, dan 5 MST), kecepatan pembentukan akar (3, 4, dan 5 MST), jumlah akar (5 MST), Panjang Akar (5 MST). Data respons kalus diamati secara visual, sedangkan variable lain dianalisis menggunakan Standar Error of Mean.

\section{HASIL DAN PEMBAHASAN}

\section{Respons Kalus Terhadap Perakaran}

Respons kalus embriogenik berbeda pada 4 kombinasi media perlakuan. Perlakuan IAA 0,5 mg+sukrosa 3\% dan IAA $1 \mathrm{mg}+$ sukrosa 5\% menunjukkan respons akar dari kalus embriogenik yang 
ditanam, sedangkan pada perlakuan 2,4-D $1 \mathrm{mg}+$ sukrosa $3 \%$ dan 2,4-D 1,5 mg+sukrosa 5\% kalus memberikan respons berupa pelebaran kalus.

Menurut Decruse, et al (2003) pembentukan tipe morfogenesis yang ingin dibentuk sangat bergantung pada kombinasi perbandingan perlakuan sitokinin dan auksin. Jafari and Khalid (2011) menyatakan jika konsentrasi auksin lebih tinggi maka akan memacu pertumbuhan tinggi dan panjang akar sedangkan jika sitokinin lebih tinggi akan memacu pertunasan.

IAA, NAA, dan IBA merupakan ZPT dari golongan auksin berpengaruh terhadap perkembangan sel, dan berfungsi merangsang pertumbuhan akar eksplan tanaman (Amin et al, 2009). Sedangkan menurut Lan, et al (2009) 2,4 D berperan dalam pembentukan embriogenesis secara langsung.

Kalus embriogenik yang ditanam dalam media MS+2,4-D baik pada konsentrasi $1 \mathrm{mg}$ ataupun 1,5 mg tidak mampu menginduksi perakaran, namun hanya memicu pertumbuhan kalus fenomena ini dijelaskan dengan pendapat Abidin (1990), kalus akan terbentuk pada media yang mengandung konsentrasi auksin dan sitokinin yang tidak seimbang dan diperjelas lagi oleh Thomas dan Chaturvendi (2008) yang mengatakan bahwa 2,4-D merupakan auksin yang memiliki daya aktivitas kuat, akan tetapi jika dikombinasikan dengan sitokinin rendah justru akan memicu pembentukan kalus. Hal ini didukung pula oleh pernyataan Gita dan Mayriska (1992), 2,4-D efektif untuk memicu pertumbuhan kalus karena aktivitasnya yang kuat untuk merangsang, proses diferensiasi sel, menekan organogenesis serta menjaga pertumbuhan kalus. Auksin yang umum digunakan pada tahap inisisasi dan multiplikasi sel adalah 2,4-D kisaran 0,5-1 mg..$^{-1}$, untuk ploriferasi kalus (Abas, 2010)

\section{Kecepatan Waktu Tumbuh Akar}

Pada Gambar 1 terlihat bahwa waktu tumbuh akar rata-rata tercepat dicapai perlakuan IAA 1 mg+sukrosa 5\% sebesar 3,98 diikuti oleh perlakuan IAA $0,5 \mathrm{mg}+$ sukrosa $3 \%$ sebesar 4,12. Sedangkan perlakuan 2,4 D (1 dan 1,5 mg) tidak memberikan respons.

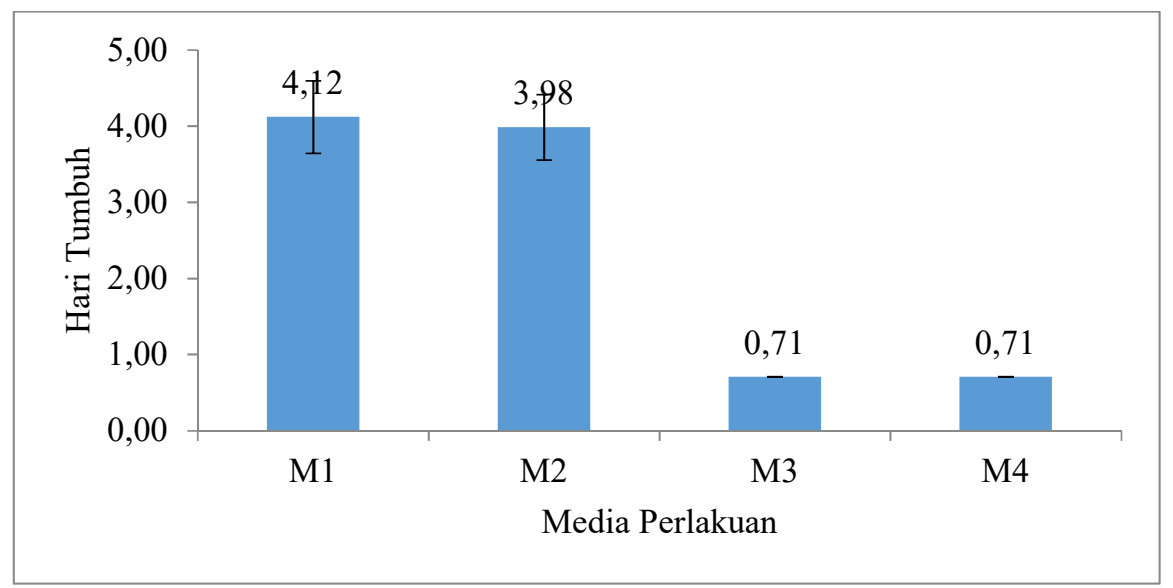

Gambar 1. Nilai rata-rata waktu tumbuh akar yang terbentuk dari kalus embriogenik tebu var kidang kencana umur 5 MST di berbagai media perlakuan.

Meskipun hasil analisis menunjukkan bahwa peningkatan IAA dan sukrosa tidak berpengaruh terhadap waktu kemunculan (hari), namun kombinasi perlakuan yang menumbuhkan akar lebih cepat 
adalah IAA $1 \mathrm{mg}+$ sukrosa 5\%. Menurut Hartman, et al (2002) bahwa inisiasi dan pembentukan akar melalui proses auksin aktif yaitu penambahan auksin eksogen harus ditambahkan. Diduga kandungan auksin endogen dalam kalus rendah sehingga media IAA $0,5+$ sukrosa $3 \%$ dan IAA $1+$ sukrosa $5 \%$ belum mampu memberikan pengaruh terhadap kecepatan waktu tumbuh akar.

Menurut Pierik (1987) Pemberian auksin pada konsentrasi tertentu dapat meningkatkan permeabilitas masuknya air ke dalam sel sehingga mempercepat pembentukan akar dan jaringan tanaman. Fenomena ini berbeda dengan yang dikemukakan Gaba (2005) bahwa konsentrasi auksin yang tinggi dapat menghambat pertumbuhan akar. Fenomena ini pun terjadi pada induksi akar mukikachu, pada rentang konsentrasi IAA 0-2,0 mg, pertumbuhan tercepat justru pada dosis 0,5 mg (Bhuiyan, 2011). Hal ini diduga auksin endogen dalam eksplan kalus rendah, sehingga pemberian taraf IAA 1 mg dapat memacU pertumbuhan lebih cepat dibandingkan dengan IAA $0,5 \mathrm{mg}$.

Sumber karbon, sumber energi, pengatur osmotik, pengatur stabilisasi membran, pelindung dari stress merupakan peran sukrosa (Ni'mah, Ratnasari, dan Budipramana, 2012). Menurut (Srilestari, 2005) media yang mengandung sukrosa lebih tinggi larutannya akan semakin pekat dari pada yang memiliki konsentrasi sukrosa lebih tinggi, sehingga arah gerakan difusinya bergerak ke konsentrasinya lebih rendah. Keadaan ini mengakibatkan sel-sel yang akan ditumbuhkan pada media yang memiliki sukrosa dengan konsentrasi lebih tinggi lebih cepat menerima unsur-unsur hara yang diperlukan bagi perkembangan dan pertumbuhannya. Kecepatan penerimaan unsur hara inilah yang memicu pertumbuhan akar lebih cepat pada media yang mengandung sukrosa dengan konsentrasi lebih tinggi dibandingkan dengan media dengan sukrosa rendah.

\section{Pengaruh Media Perlakuan Terhadap Panjang Akar}

Pengamatan panjang akar dilaksanakan setelah 5 MST setelah kalus embriogenik di tanam di media perlakuan. Pada Gambar 2 terlihat bahwa jumlah akar rata-rata terbanyak dicapai perlakuan IAA 1 mg+sukrosa 5\% sebesar 1,56 diikuti oleh perlakuan IAA $0,5 \mathrm{mg}+$ sukrosa $3 \%$ sebesar 1,40 dan yang terendah dicapai perlakuan 2,4-D $1 \mathrm{mg}+$ sukrosa 3\% dan 2,4-D 1,5 mg+sukrosa 3\% dengan rata-rata 0,71 (Media tidak mampu menginduksi akar).

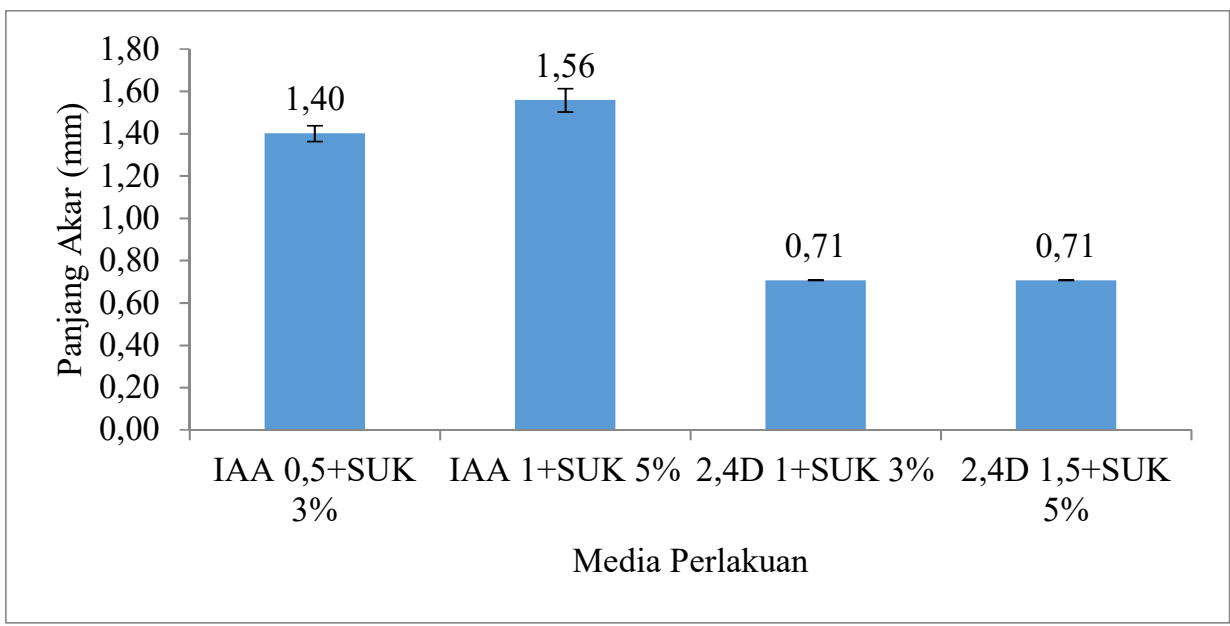

Gambar 2. Nilai rata-rata perbandingan panjang akar yang terbentuk dari kalus embriogenik tebu var. kidang kencana umur 5 MST di berbagai media perlakuan. 
Perlakuan IAA $1 \mathrm{mg}+$ sukrosa 5\% berbeda nyata dengan perlakuan lain dan memiliki nilai rata-rata tertinggi. Hal ini sejalan dengan penelitian Lestari (1999) dosis IAA 1 mg menghasilkan akar terbanyak dan terpanjang pada tanaman inggu dibandingkan d osis lain. Menurut (Davies, 1995) Golongan ZPT auksin dapat menginisiasi akar dan memacu pertumbuhan cabang pada kultur jaringan.

Fenomena tersebut diduga didukung kontribusi kombinasi yang terdapat didalam media yaitu sukrosa dan air kelapa. Ni'mah, Ratnasari dan Budipramana (2012) melaporkan bahwa penambahan sukrosa pada konsentrasi tertentu mampu mempercepat jaringan eksplan yang ditumbuhkan pada media menerima unsur-unsur yang dibutuhkan bagi pertumbuhan dan perkembangan. Samudera, Rianto dan Historiawati (2017) Tahap pengakaraan eksplan tebu sangat membutuhkan pasokan energi dan sumber karbon dengan jumlah cukup besar untuk pertumbuhan akar-akar baru. Dalam penelitiannya Tesfa, Admassu dan Bantte (2016) mengatakan bahwa sukrosa merupakan sumber karbohidrat atau media dalam pengakaran sehingga berpengaruh secara signifikan terhadap induksi akar.

Mandang (1993) melaporkan bahwa air kelapa dapat meningkatkan IAA dalam jaringan dan memenuhi kebutuhan pertumbuhan dan morfogenesis kultur sehingga dapat mendukung induksi akar. Hal ini berbeda dengan pendapat Delvin (1975) yang mengatakan bahwa pemberian IAA pada konsentrasi yang lebih tinggi pada akar dapat menyebabkan terhambatnya pemanjangan akar. Diduga hal ini karena kandungan auksin endogen dalam eksplan rendah sehingga taraf IAA $1 \mathrm{mg} . \mathrm{l}^{-1}$ justru memberikan pemanjangan akar yang lebih baik dibandingkan IAA $0,5 \mathrm{mg} \cdot \mathrm{l}^{-1}$. Winata (1987) menyatakan bahwa penambahan ZPT auksin maupun sitokinin ke dalam media kultur dapat meningkatkan konsentrasi zat pengatur endogen didalam eksplan, sehingga menjadi faktor pemicu dalam proses tumbuh dan perkembangan jaringan.

\section{Pengaruh Media Perlakuan pada Jumlah Akar}

Pengamatan panjang akar dilaksanakan setelah 5 MST setelah kalus embriogenik di tanam di media perlakuan. Pada Gambar 3 terlihat bahwa jumlah akar rata-rata terbanyak dicapai perlakuan IAA 1 mg+sukrosa 5\% sebesar 2,08 diikuti oleh perlakuan IAA $0,5 \mathrm{mg}+$ sukrosa 3\% sebesar 1,49 dan yang terendah dicapai perlakuan 2,4-D $1 \mathrm{mg}+$ sukrosa 3\% dan 2,4D 1,5 mg. $l^{-1}+$ sukrosa 3\% dengan rata-rata 0,71 (Kalus tidak tumbuh menjadi akar).

Hal ini sejalan dengan penelitian Lestari (2011) yang menyebutkan penggunaan IAA $1 \mathrm{mg}$ sangat berpengaruh terhadap panjang akar dan jumlah akar. Hartman, et al (2002) menyebutkan jumlah akar juga berlaku untuk perpanjangan akar.

Menurut pendapat Putri, et al (2018) hormon IAA merupakan hormon yang berperan dalam diferensiasi sel dan menginisiasi pembentukan akar tanaman.

Widiastoety (2014) menyebutkan bahwa pembentukan akar berhubungan dengan kandungan auksin dan sitokinin endogen dalam jaringan tanaman, selanjutnya diikuti oleh proses pemanjangan dan pembesaran sel. 


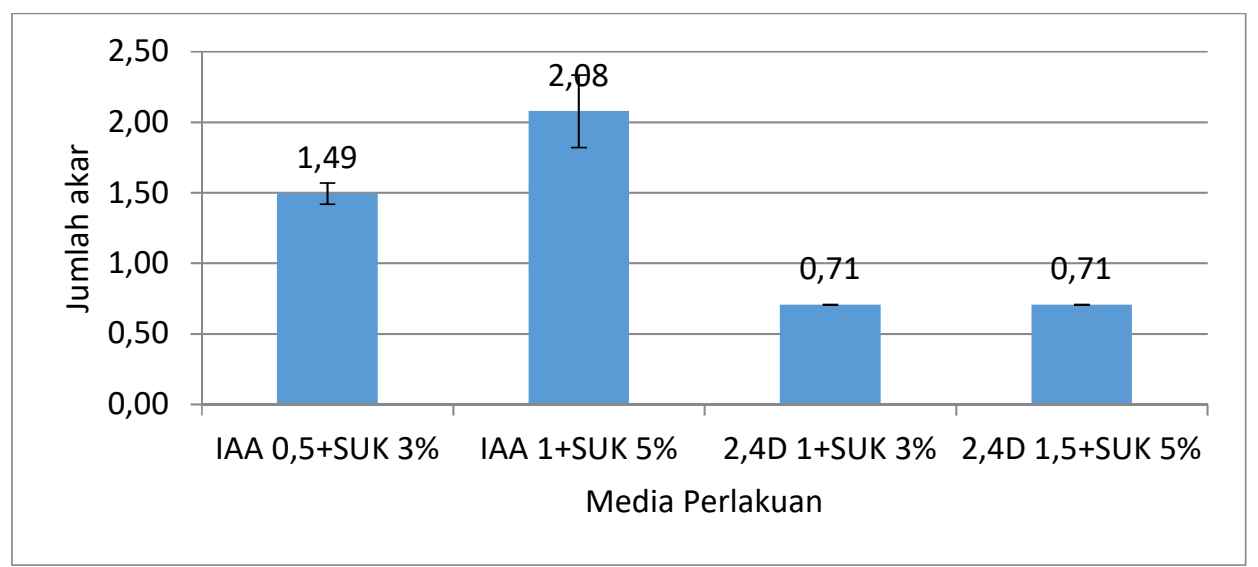

Gambar 3. Nilai rata-rata perbandingan jumlah akar yang terbentuk dari kalus embriogenik tebu var. kidang kencana umur 5 MST di berbagai media perlakuan.

\section{KESIMPULAN}

Komposisi media terbaik dalam menginduksi akar dari kalus embriogenik tanaman tebu adalah IAA 1 mg. $l^{-1}$ dengan kombinasi sukrosa 5\%. Peningkatan konsentrasi IAA dan sukrosa hanya berpngaruh pada panjang dan jumlah akar.

\section{DAFTAR PUSTAKA}

Abbas, B., 2011, Prinsip-prinsip dasar kultur jaringan, Alfabeta, Bandung.

Abidin, Z., 1985, Dasar-dasar pengetahuan tentang Zat Pengatur Tumbuh, Angkasa, Bandung.

Amin, M. D, M.R, Karim, M.R, Amin, S, Rahman and A.N.M, Mamun, 2009, In vitro micropropagation of Banana, Agri Res, hlm 645-659.

Bhuiyan, M. K.R, M.J, Hossain, M.S, Rahman, S.M.L, Rahman, and A, Sattar, 2011, Root initiation in mukikachu (Colocasia esculenta) as influenced by IAA and NAA, Bangladesh Journal Agrio, hlm 478-494.

Davies, P.J, 2004, Plant Hormones : Biosyntesis, signal transduction,action, Kluwer Academic Publiser, New York.

Decruse, S. W, A, Ganganprasa, S, Seeni., and M, Sarajini, 2003, Micropropagation and ecorestoration of vanda spathulata, Plant cell tissue and organ culture, Vol 2, hlm 199-202.

Delvin, R.M, 1975, Plant Phisiology, Nostard Company, New York.

Gaba, V.P., 2005, Plant Growth Regulator, London, hlm 87-100.

Gita, E, and I, Mayriska , 1992, Penaruh auksin dann sitokinin terhadap kalus Mentha Pipera Linn, Litri, hlm $1-4$. 
Hartmann, D. P. S, D.E, Ketser, F.T, Davier, and R.L, geneve, 2002, Plant propagation principles and practise, Prentice Hall, New Jersey.

Jafari, N. R. Y.O, and N, Khalid, 2011, Effeect Benzylaminopurine (BAP) pulsing on in vitro shoot multiplication of Musa acuminate (Banana), Journal Biotechol, hlm 2446-2450.

Kemenperin. 2018, Industri gula digenjot, https://Kemenperin.go.id/artikel/20447/industri-gula-digenjot, diakses tgl 24 September 2019.

Lan, T. H, P.L, Huang, C.C, Chang, and C.C, Lin, 2009, High Frecuency direct somatic embryogenesis from leaf tissue of Drimiopsis kirkii baker (Giant Squill), Biol Plant, Vol 45, hlm 44-47.

Lestari, E.G, dan Husni, 1997, Regenerasi tunas adventif dari jaringan batang dan kalus tanaman inggu, Prosiding Simposium Hasil Penel;itian dan Pengembangan anaman Indusri, Bogor, 21-23 Novmber 1997, hlm 58-61.

Mandang, J.P, 1999, Peranan Air Kelapa dalam kultur jaringan tanaman krisanan (Chyrysanthmun morifolium), Disertasi, Institut Pertanian Bogor, Bogor.

Minarsih, H. 2013. Mikropropagasi plantlet tebu menggunakan system perndaman sesaat. Jurnal Menara Perkebunan, hlm 18.

Ni'mah, F, Ratnasari, dan Budipramana, 2012, Pengaruh brbagai pemberian sukrosa dan kinetin terhadap induksi umbi mikro kentang (Solanum tuberosum L.) kultivar kembang secara in viro, Lentera bio, hlm 41-48.

Pierik, R.L.M, 1987, In vitro culture of hihr plans, kluwer academic publisher, USA.

Putri, R.R.D., Suwirnem, dan N, Nasril, 2018, Pengaruh NAA pada pertumbuhan pisang raja kinalun secara invitro, Jurnal Biologi Universitas Andalas, hlm 1-5.

Samudera, A.A, H. Rianto, dan Historiawati, 2019, Pengakaran In Vitro Eksplan Tebu (Saccharum officinarum) varietas Bululawang pada berbagai konsentrasi NAA dan sukrosa terhadap perumbuhan plantlet tebu, Lentera bio, hlm 41-48.

Srilestari, 2005, Induksi embrio somatik kacang tanah pada berbagi macam vitamin dan sukrosa, :http://agrisci.ugm.ac.id/vol12_1.kacang/5.kacang_srilestari.pdf, diakses tanggal 1 Februari 2019.

Tesfa, M.B, Admassu, and K, Bantte, 2016, In Vitro Rooting and acclimization of micropropagated elite sugarcane (Saccharum officinarum) Genotyps N52 and N53, Journal tissue science \& engginering, hlm 1-6.

Thomas, T.D, and R, Chaturvendi, 2008, Endosprem culture : a novel method for triploid plant production, Plant cell tissue and organ culture, Vol 93, hlm 1-14.

Wijayanti, I., Isda, dan W, Lestari., 2015. Induksi Jeruk Siam Asal Kampar (Citrus nobilis Lour.), Jurnal FMIPA, hlm 114-152

Winata, L., 1987, Teknik kultur jaringan, PAU Bogor, Bogor. 